\title{
Developmental Upregulation of Human Parathyroid Hormone (PTH)/PTH-related Peptide Receptor Gene Expression from Conserved and Human-specific Promoters
}

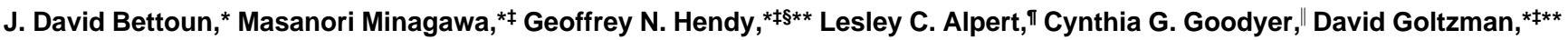 \\ and John H. White ${ }^{\star}$ \\ *Department of Physiology, ${ }^{\ddagger}$ Department of Medicine, and ${ }^{\S}$ Department of Human Genetics, McGill University, Montreal, Quebec H3G \\ 1Y6, Canada; "Department of Pediatrics, Montreal Children's Hospital and McGill University, Montreal, Quebec H3P 1P3, Canada; \\ "Department of Pathology, and McGill Centre for Translational Research in Cancer, Jewish General Hospital, Montreal, Quebec H3T \\ 1E2, Canada; and **Calcium Research Laboratory, McGill University and Royal Victoria Hospital, Montreal, Quebec H3A 1A1, Canada
}

\begin{abstract}
The parathyroid hormone (PTH)/PTH-related peptide (PTHrP) receptor (PTHR) functions in skeletal development and mediates an array of other physiological responses modulated by PTH and PTHrP. PTHR gene transcription in mouse is controlled by two promoters: P1, which is highly and selectively active in kidney; and P2, which functions in a variety of tissues. P1 and P2 are conserved in human tissue; however, P1 activity in kidney is weak. We have now identified a third human promoter, P3, which is widely expressed and accounts for $\sim 80 \%$ of renal PTHR transcripts in the adult. No P3 activity was detected in mouse kidney, indicating that renal PTHR gene expression is controlled by different signals in human and mouse. During development, only $\mathbf{P} 2$ is active at midgestation in many human tissues, including calvaria and long bone. This strongly suggests that factors regulating well conserved P2 control PTHR gene expression during skeletal development. Our results indicate that human PTHR gene transcription is upregulated late in development with the induction of both $\mathrm{P} 1$ and $\mathrm{P} 3$ promoter activities. In addition, $\mathrm{P} 2$-specific transcripts are differentially spliced in a number of human cell lines and adult tissues, but not in fetal tissues, giving rise to a shorter and less structured $5^{\prime}$ UTR. Thus, our studies show that both human PTHR gene transcription and mRNA splicing are developmentally regulated. Moreover, our data indicate that renal and nonrenal PTHR gene expression are tightly coordinated in humans. (J. Clin. Invest. 1998. 102:958-967.) Key words: gene transcription • differential splicing • fetal development • calcium homeostasis • tissue-specific promoter
\end{abstract}

Address correspondence to John H. White, The Department of Physiology, McIntyre Medical Sciences Building, McGill University, 3655 Drummond Street, Montreal, Quebec H3G 1Y6, Canada. Phone: 514-398-8498; FAX: 514-398-7452; E-mail: jwhite@physio.mcgill.ca Masanori Minagawa's present address is Department of Pediatrics, Chiba University School of Medicine, 1-8-1 Inohana, Chuo-ku, Chiba 260, Japan.

Received for publication 9 April 1998 and accepted in revised form 25 June 1998.

J. Clin. Invest.

(C) The American Society for Clinical Investigation, Inc. 0021-9738/98/09/0958/10 \$2.00

Volume 102, Number 5, September 1998, 958-967

http://www.jci.org

\section{Introduction}

Signaling through the parathyroid hormone $(\mathrm{PTH})^{1} / \mathrm{PTH}-$ related peptide (PTHrP) receptor (PTHR) is essential for normal development and a wide array of physiological responses stimulated by PTH and PTHrP. PTH is released from the parathyroid glands in response to decreased extracellular fluid calcium levels, and binds to PTHRs expressed in kidney and bone. Stimulation of renal and osseous PTHRs increases extracellular fluid calcium concentrations by enhancing calcium reabsorption and mobilization and phosphate excretion $(1,2)$. PTHrP can mimic many of the effects of PTH when overexpressed by cancers. Physiologically, PTHrP acts in a paracrine/ autocrine manner, in contrast to PTH. Whereas production of PTH is restricted to the parathyroids, PTHrP is widely expressed and functions to modulate cellular growth and differentiation (3-6). Like PTHrP, the PTHR is widely expressed. In the rat, the PTHR is expressed at its highest levels in kidney and at lower levels in a number of tissues, including bone, bladder, aorta, heart, liver, lung, and spleen $(7,8)$.

The essential role of the PTHR in skeletal development has been highlighted by studies of Jansen-type metaphyseal chondrodysplasia, a rare form of dwarfism associated with hypercalcemia despite near normal circulating levels of PTH and PTHrP. Mutations in transmembrane domains of the PTHR in these patients lead to constitutive activation of the receptor (9-11). Gene ablation studies in mice have shown that PTHrPPTHR signaling is essential for normal endochondral ossification (12-14). PTHrP and PTHR null mice displayed similar phenotypes, with reduced proliferation and accelerated maturation of chondrocytes associated with accelerated ossification.

The PTHR belongs to the vast family of G protein-coupled receptors containing seven transmembrane domains. Binding of ligand can stimulate production of intracellular cAMP and inositol 1,4,5-trisphosphate (15-17). The structure of the PTHR gene is very similar to those of receptors for peptide hormones, including calcitonin, vasoactive intestinal peptide, glucagon, and growth hormone releasing peptide (18-23), providing evidence that these receptors have evolved from a common precursor.

Two promoters control PTHR gene transcription in the mouse and rat, $\mathrm{P} 1$ and $\mathrm{P} 2$, which give rise to transcripts differing in their $5^{\prime}$ untranslated regions (UTRs) but not their coding sequences $(18,24,25)$. $\mathrm{P} 1$ is highly and selectively active in mouse kidney and accounts for at least $90 \%$ of renal PTHR

1. Abbreviations used in this paper: 5' UTR, 5' untranslated region; PHP1b, pseudohypoparathyroidism type 1b; PTH, parathyroid hormone; PTHrP, PTH-related peptide; PTHR, PTH/PTHrP receptor; SS, single stranded. 
transcripts $(25,26)$. P1 activity in bone and cartilage is very weak or absent (25, unpublished results). Unlike P1, P2 is expressed at moderate levels in a number of tissues and controls the broad expression pattern of the PTHR. P2 is highly $(\mathrm{G}+$ $\mathrm{C}$ )-rich and has all the hallmarks of a housekeeping promoter. The expression patterns of P1- and P2-specific transcripts in mouse suggest that renal and nonrenal transcription of the PTHR gene are regulated largely by different mechanisms.

The exon-intron structures of the coding regions of the human and rodent PTHR genes are highly conserved (19). P1 and P2 are also conserved between mouse and human (27). However, studies with kidney RNA suggested that human P1 is not as active as its mouse counterpart. Here we have further characterized the human PTHR gene and have discovered a third promoter, $\mathrm{P} 3$, which is active in kidney, bone, and other tissues. P3 accounts for $\sim 80 \%$ of detectable renal PTHR transcripts in human but is apparently inactive in mouse kidney. Elucidation of the normal regulation of human PTHR gene expression will provide insights into various disorders of calcium homeostasis and development. Our data show that both PTHR gene transcription and mRNA splicing are developmentally regulated and suggest that PTHR gene expression in adults is coordinated differently in human and mouse.

\section{Methods}

Tissues and RNA extraction. Protocols for obtaining human and mouse tissues were approved by local ethics committees. Tissues from human fetuses $(n=7,11.75-19$ wk fetal age $)$ were obtained at the time of therapeutic abortion. All tissues were flash frozen and stored immediately at $-70^{\circ} \mathrm{C}$. Long bone samples were taken from the femur and muscle samples from the thigh. Fetal age (FA) was determined by foot length (28). Total RNA was isolated from adult tissue or cultured cells by $\mathrm{CsCl}$ gradient centrifugation and from fetal tissues using Trizol (GIBCO BRL Life Technologies, Grand Island, NY) extraction.

Ribonuclease (RNase) protection analysis. RNase protection probes for U1- and U3-containing transcripts have been described (reference 5; Fig. $1 A$ ). A U4 probe was created from a 1.8-kb KpnI-BamHI fragment containing the single-stranded (SS) exon inserted in Bluescript SK+, which was digested with Apa1 and in vitro transcribed with T3 RNA polymerase (New England Biolabs, Beverly, MA) under standard conditions (see Fig. $1 A$ ). Probes $\left(10^{5} \mathrm{cpm}\right)$, purified on Sephadex G50 spin columns, were precipitated with $20 \mu \mathrm{g}$ of total RNA, resuspended in $30 \mu \mathrm{l}$ of hybridization buffer $(80 \%$ deionized formamide, $40 \mathrm{mmol} /$ liter piperazine- $\mathrm{N}, \mathrm{N}^{\prime}$-bis-2-ethanesulphonic acid (pH 6.4), $0.4 \mathrm{~mol} /$ liter sodium acetate, and $1 \mathrm{mmol} /$ liter ethylenediaminetetraacetate), denatured for $5 \mathrm{~min}$ at $85^{\circ} \mathrm{C}$, and incubated overnight at $50^{\circ} \mathrm{C}$. Digestions were performed for $1 \mathrm{~h}$ at $37^{\circ} \mathrm{C}$ with $4 \mathrm{U}$ of RNase 1 (Promega Co., Madison, WI) according to manufacturer's specifications. Products were ethanol precipitated and electrophoresed on a $6 \%$ polyacrylamide sequencing gel. The integrity of the probe was verified by running $250 \mathrm{cpm}$ of undigested mix.

Primer extension analysis. Ten picomoles of primer P3Up2 (5'CTATGGGACCCCGGCGTCC-3'), which is complementary to sequences starting $61 \mathrm{bp}$ upstream of the SS exon, was labeled for $1 \mathrm{~h}$ at $37^{\circ} \mathrm{C}$ with $\left[{ }^{32} \mathrm{P}\right] \gamma$-ATP using T4 polynucleotide kinase. One tenth of this reaction was incubated with $10 \mu \mathrm{g}$ of either adult human kidney total RNA or yeast tRNA as a control, overnight at $55^{\circ} \mathrm{C}$ in $300 \mathrm{mM}$ $\mathrm{KCl}, 20 \mathrm{mM}$ Tris- $\mathrm{HCl}$ (pH 8.3), 2 mM EDTA in a final volume of 26 $\mu l$. Samples were then put on ice, and $4 \mu \mathrm{l}$ of $25 \mathrm{mM}$ Tris- $\mathrm{HCl}(\mathrm{pH}$ 8.0), $60 \mathrm{mM} \mathrm{MgCl}$, $10 \mathrm{mM}$ DTT, $5 \mathrm{mM}$ dNTPs, $2 \mathrm{U}$ of RNAguard (Pharmacia, Uppsala, Sweden), and $100 \mathrm{U}$ of M-MLV reverse transcriptase (GIBCO BRL) was added. After $60 \mathrm{~min}$ at $43^{\circ} \mathrm{C}$, enzymes were inactivated for $10 \mathrm{~min}$ at $75^{\circ} \mathrm{C}$, and the reaction was extracted with phenol and ethanol precipitated. One quarter of the reaction was denatured for $2 \mathrm{~min}$ at $80^{\circ} \mathrm{C}$ and run on a $6 \%$ denaturing polyacrylamide gel along with sequencing reactions as molecular weight markers.

Reverse transcription-polymerase chain reaction $(R T-P C R)$ analysis and $c D N A$ cloning. Three micrograms of total RNA was precipitated, resuspended in $6 \mu \mathrm{l}$ of $1 \times$ DNase I digestion buffer (Promega) containing $0.5 \mathrm{U}$ of DNase I, incubated for $15 \mathrm{~min}$ at $37^{\circ} \mathrm{C}$ and for 10 $\min$ at $75^{\circ} \mathrm{C}$, and put on ice. Two microliters was added to $18 \mu \mathrm{l}$ of a RT mix containing $0.5 \mathrm{mmol} /$ liter of each $\mathrm{dNTP}, 5 \mathrm{mmol} /$ liter of DTT, $1 \mu \mathrm{mol} /$ liter of $6 \mathrm{mer}$ random primers, $75 \mathrm{mmol} / \mathrm{liter}$ of $\mathrm{KCl}, 3 \mathrm{mmol} /$ liter of $\mathrm{MgCl}_{2}$ in $50 \mathrm{mmol} /$ liter of Tris- $\mathrm{HCl}(\mathrm{pH} \mathrm{8.3)}$, and incubated for $1 \mathrm{~h}$ at $37^{\circ} \mathrm{C}$, followed by $75^{\circ} \mathrm{C}$ for $10 \mathrm{~min}$. For detection of P1-specific transcripts by PCR, $2 \mu \mathrm{l}$ of the RT reaction was subjected to a first round of 30 cycles of amplification $\left(95^{\circ} \mathrm{C}\right.$ for $30 \mathrm{~s}, 56^{\circ} \mathrm{C}$ for $1 \mathrm{~min}$, $72^{\circ} \mathrm{C}$ for $20 \mathrm{~s}$ ), using $5^{\prime}$-AGGGAATTCAGGTCTTTTCTTGTCCCCAGC-3' as the forward primer (primer 1) and 5'-GACGTCATCTGCATCCACCAGCGC-3' (primer 6) as the reverse primer. One microliter of the first reaction was then subjected to 30 more cycles of amplification $\left(95^{\circ} \mathrm{C}\right.$ for $30 \mathrm{~s}, 58^{\circ} \mathrm{C}$ for $1 \mathrm{~min}$, and $72^{\circ} \mathrm{C}$ for $5 \mathrm{~s}$ ), using forward primer $5^{\prime}$-AGTTGTGTGTCCTGGACACTACCA-3' (primer 2) and reverse primer 5'-GCCTCCCCGTGGCCAACTTGAGTC-3' (primer 3). PTHR and $\beta$-actin coding sequences were detected by amplification of $2 \mu \mathrm{l}$ of the RT reaction for 24 cycles $\left(95^{\circ} \mathrm{C}\right.$ for $30 \mathrm{~s}, 56^{\circ} \mathrm{C}$ for $1 \mathrm{~min}$, and $72^{\circ} \mathrm{C}$ for $\left.25 \mathrm{~s}\right)$. The forward primer for the PTHR was 5'-CACCACTACTACTGGATTCTGGTG-3', and the reverse primer used was $5^{\prime}$-GATTTCTTGATCTCGCTTGTACC- $3^{\prime}$. For $\beta$-actin, the forward primer was $5^{\prime}$-GCTGTGCTATCCCTGTACGC-3' and the reverse primer was 5'-GCCATGGTGATGACCGGC-3'. All of the above reactions were performed in $50 \mu \mathrm{l}$ of $1.5 \mathrm{mmol} /$ liter of $\mathrm{MgCl}_{2}, 50 \mathrm{mmol} / \mathrm{liter}$ of $\mathrm{KCl}$, and $10 \mathrm{mmol} / \mathrm{liter}$ of Tris- $\mathrm{HCl}$ ( $\mathrm{pH}$ 9.0) using $2.5 \mathrm{U}$ of Taq DNA polymerase (Pharmacia). $\mathrm{P} 3$-specific transcripts were detected using 28 cycles of PCR $\left(95^{\circ} \mathrm{C}\right.$ for $30 \mathrm{~s}, 58^{\circ} \mathrm{C}$ for $45 \mathrm{~s}$, and $72^{\circ} \mathrm{C}$ for $15 \mathrm{~s}$ ), performed using $2 \mu \mathrm{l}$ of RT reaction in $50 \mu \mathrm{l}$ of $0.8 \mathrm{mmol} /$ liter of $\mathrm{MgCl}_{2}, 50 \mathrm{mmol} / \mathrm{liter}$ of $\mathrm{KCl}, 20$ $\mathrm{mmol} /$ liter of Tris- $\mathrm{HCl}(\mathrm{pH} 8.3$ ), and $2.5 \mathrm{U}$ of Taq DNA polymerase, and 5'-ACGGAATTCCAGCCTGACGCAGCTCTGCACC-3' (primer 5) and primer 6 (see above) as forward and reverse primers, respectively. Amplification of $\mathrm{P} 2$-specific transcripts was performed by subjecting $1 \mu \mathrm{l}$ of the RT reaction to a touch-down PCR as follows: $45 \mathrm{~s}$ denaturation at $95^{\circ} \mathrm{C}, 20 \mathrm{~s}$ elongation at $72^{\circ} \mathrm{C}$, and $1 \mathrm{~min}$ annealing starting at $58^{\circ} \mathrm{C}$, down $1^{\circ} \mathrm{C}$ per cycle to $51^{\circ} \mathrm{C}$, under which conditions 25 cycles of amplification were performed. The reaction was in $20 \mu \mathrm{l}$ of $1.5 \mathrm{mmol} / \mathrm{liter}$ of $\mathrm{MgCl}_{2}, 50 \mathrm{mmol} / \mathrm{liter}$ of $\mathrm{KCl}$, and 10 $\mathrm{mmol} /$ liter of Tris- $\mathrm{HCl}(\mathrm{pH} \mathrm{9.0)}$ and in $5 \%$ formamide and $5 \mathrm{U}$ of Taq DNA polymerase. The forward primer was $5^{\prime}$-GCCCGACATCCTGCAAGGC-3' (primer 4), and the reverse primer was primer 6 (see above). PCR reactions ( $2 / 5$ to $1 / 10)$ were run on a $2 \%$ agarose gel, transferred overnight to a nylon Hybond $\mathrm{N}+$ membrane (Amersham, Arlington Heights, IL), and the DNA was covalently attached by baking the membrane at $80^{\circ} \mathrm{C}$ under vacuum for $2 \mathrm{~h}$. Membranes were prehybridized for $30 \mathrm{~min}$ in $6 \times$ NET $(100 \mathrm{mM}$ Tris- $\mathrm{HCl}[\mathrm{pH}$ 7.5], $0.9 \mathrm{M} \mathrm{NaCl}, 6 \mathrm{mM}$ EDTA), $10 \times$ Denhardt's, $0.5 \%$ SDS, $10 \mathrm{mg} /$ $\mathrm{ml}$ denatured salmon sperm DNA at $62^{\circ} \mathrm{C}$, and then hybridized in $6 \times$ NET, $5 \times$ Denhardt's, $0.5 \%$ SDS, $1 \mathrm{mg} / \mathrm{ml}$ denatured salmon sperm DNA with $10^{6} \mathrm{cpm}$ of end-labeled oligonucleotides for $5 \mathrm{~h}$ at $62^{\circ} \mathrm{C}$. Oligonucleotides used for probing were: $5^{\prime}$-CCCTAGGCGGTGGCGATGGGGACC-3', for P2- and P3-containing sequences, 5' -CTGCAGCTTTAGGCCCGACTTG-3' for P1-specific sequence, and 5'TGGCCATGAAGACAATGTAGTGGACG-3' for coding sequence. To clone P2-specific cDNA sequences amplified from HOS cell extracts, cDNA fragments amplified as described above were subjected to 30 more cycles of PCR (45-s denaturation at $95^{\circ} \mathrm{C}, 20$-s elongation at $72^{\circ} \mathrm{C}$, and $1-\mathrm{min}$ annealing at $51^{\circ} \mathrm{C}$ ). The amplified band was purified from a $2 \%$ agarose gel, inserted in the TA cloning vector pPCR2 (Invitrogen, San Diego, CA), and characterized by DNA sequencing. Secondary structure analysis of 5' UTRs of P2-specific transcripts was performed with Squiggles (GCG package, University of Wisconsin). 
Construction of PTHR promoter-luciferase reporter vectors. To construct the P1-luciferase reporter plasmid pXP2-P1, a 1.6-kb fragment of $\mathrm{P} 1$ extending from a BamHI site $1428 \mathrm{bp}$ upstream of the most $5^{\prime}$ transcription start site $(+1)$ to a PstI site at position +174 (27) was inserted in BamHI-PstI-digested pSKb, a derivative of pBluescript $\mathrm{SK}+$ (Stratagene, La Jolla, CA) in which the XbaI site has been converted into a BglII site. The insert was excised from pSKb as a BamHI-BglII fragment and inserted in the polylinker of the promoterless luciferase plasmid pXP2 (29). To construct P2-luciferase recombinant pXP2-P2, a 1.1-kb SacI fragment (containing P2 se- quences -959 to +101 ), whose ends were rendered blunt with T4 polymerase, was inserted into the SpeI site of pSKb. Insert orientation was confirmed by restriction digestion and DNA sequencing. The insert was excised as a BamHI-BglII fragment and subcloned into pXP2. To construct pXP2-P3, a $1.1 \mathrm{~kb}$ NcoI-AvrII fragment $(-843$ to +245$)$ was rendered blunt with $\mathrm{T} 4$ polymerase and inserted into the SpeI site of SKb. The resulting BamHI-BglII fragment was excised and inserted in the polylinker of pXP2.

Cell culture and transient transfections. SaOS-2 cells (ATCC) were propagated in McCoy 5A media $+10 \%$ fetal bovine serum. HOS and

A.

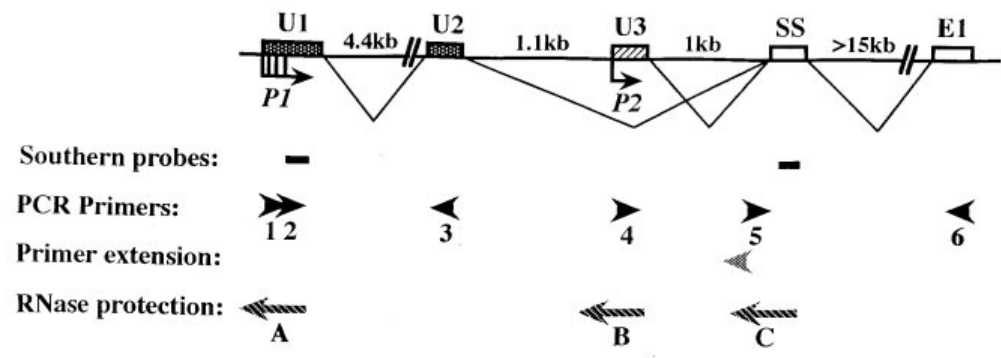

B.

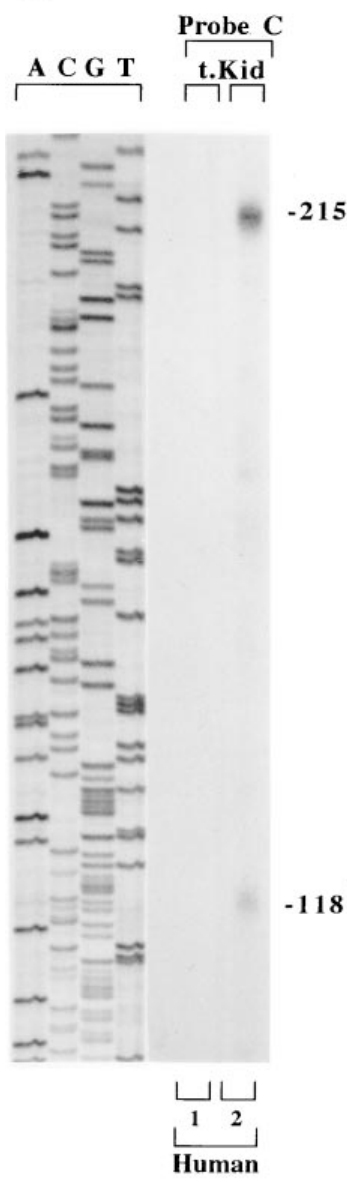

C.

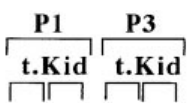

D.
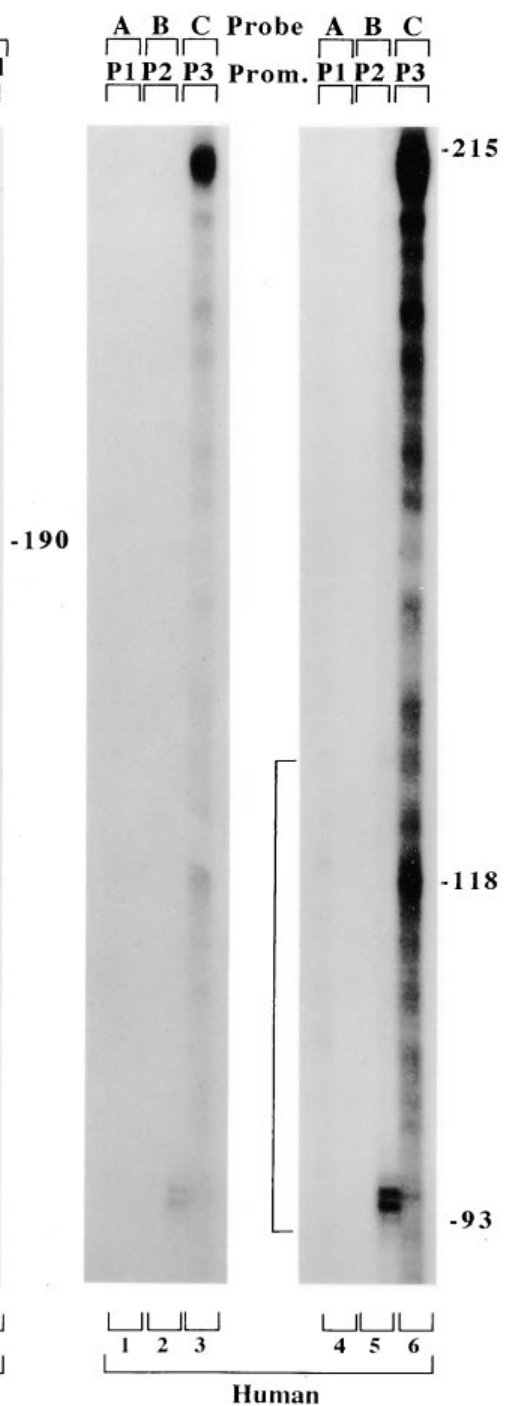

Figure 1. Detection of a third human PTHR gene promoter. (A) Schematic representation of the $5^{\prime}$ end of the human PTHR gene. UTR exons U1, $\mathrm{U} 2$, and $\mathrm{U} 3$ are indicated along with the signal sequence exon (SS) and the first extracellular domain exon E1. Splicing patterns of transcripts expressed from $\mathrm{P} 1$ and $\mathrm{P} 2$ promoters are shown up to E1. Probes used for Southern analysis, primers used for PCR (numbered 1-6) and primer extension, and probes A, B, and C used for RNase protection assays of human RNA presented below are indicated. $(B)$ RNase protection analysis of transfer RNA control $(t$.) and adult human total kidney RNA (Kid) samples using probe $\mathrm{C}$, which corresponds to human genomic sequences encompassing SS and sequences $5^{\prime}$ to SS. The 118 -b protected product expected from previously characterized splicing pattern as well as a 215 -b product are indicated. $(C)$ RNase protection experiments performed with tRNA $(t$.) control or mouse total adult kidney RNA (Kid) using a mouse P1-specific probe (lanes 1 and 2; reference 25), and a probe extending $1 \mathrm{~kb}$ downstream from a BamHI site at the $3^{\prime}$ end of U3 to an AvrII site 30 bp downstream of the $5^{\prime}$ end of SS of the mouse gene (lanes 3 and 4). A major protected P1-specific fragment of $190 \mathrm{~b}$ is indicated. $(D)$ RNase protection experiments of adult human total kidney RNA with human probes $\mathrm{A}, \mathrm{B}$, and $\mathrm{C}$ corresponding to $\mathrm{P} 1, \mathrm{P} 2$, and $\mathrm{P} 3$ promoter regions, respectively. Short (lanes 1-3) and longer exposures (lanes 4-6) are presented. The 215- and 118-b fragments protected by the $\mathrm{P} 3$-specific probe $\mathrm{C}$, and a $93-\mathrm{b}$ product protected by the $\mathrm{P} 2$-specific probe $B$ are indicated. Several bands protected by the $\mathrm{P} 1$-specific probe $\mathrm{A}$ are only seen in the longer exposure (lane 4 , bracketed). 
U2OS cells (ATCC) were cultured in DMEM $+10 \%$ fetal calf serum. HK-2 cells (30) were propagated in keratinocyte serum-free medium + $5 \mathrm{ng} / \mathrm{ml}$ epidermal growth factor, and $50 \mu \mathrm{g} / \mathrm{ml}$ bovine pituitary extract (GIBCO), and MCF-7 cells were propagated in Eagle's MEM $+10 \%$ fetal bovine serum. Transient transfections were performed with HOS cells $(50 \%$ confluent) grown in 12 -well plates. Cells were transfected with $1 \mu \mathrm{g}$ of luciferase reporter plasmid and $250 \mathrm{ng}$ of $\beta$-galactosidase expression vector p610AZ (31) using Lipofectin (GIBCO), according to the manufacturer's instructions. Media were changed $12 \mathrm{~h}$ later, and cells were harvested in $100 \mu$ l of Reporter Lysis Buffer (Promega) $72 \mathrm{~h}$ after transfection. Luciferase assays were performed according to instructions (Promega), and $\beta$-galactosidase assays to normalize for transfection efficiency were performed as previously described (32).

\section{Results}

Identification of a major PTHR promoter, P3, active in human but not mouse kidney. We have previously identified two promoters, $\mathrm{P} 1$ and $\mathrm{P} 2$ (Fig. $1 A$ ), which control human PTHR transcription (27). While these two promoters are conserved between human and mouse $(18,25)$, expression of $\mathrm{P} 1$ in the human kidney is weak, whereas in the mouse, P1 activity accounts for at least $90 \%$ of renal transcripts $(25,26)$. Preliminary RNase protection experiments suggested that the combined activities of human P1 and P2 could not account for the levels of PTHR transcripts detected with coding sequence probes (data not shown). We therefore investigated whether there were other promoter sequences controlling PTHR gene expression in human kidney.

An RNase protection experiment performed with human kidney total RNA and a human genomic probe extending upstream of signal sequence exon SS (Fig. $1 A$, Probe $C$ ) protected a 118-b fragment. This corresponds to splicing of SS to the $5^{\prime}$ untranslated region exons (5' UTRs) of transcripts expressed from P1 or P2 (Fig. $1 B$, lane 2). The probe also protected an abundant, larger fragment of $215 \mathrm{~b}$, consistent with transcription from a promoter, hereafter called $\mathrm{P} 3$, giving rise to a fusion exon composed of a $5^{\prime}$ UTR and the SS exon (see below). An identical result was obtained with total RNA from an independent kidney sample (data not shown). Significantly, no protected fragment was detected using a probe derived from mouse genomic sequences upstream of SS, under conditions where mouse P1-specific transcripts were detected at high levels (Fig. $1 C$, lanes 2 and 4 ), indicating that similar transcripts are not expressed at significant levels in mouse kidney.

The relative intensities of the 215- and 118-b protection products suggested that $\mathrm{P} 3$ activity accounts for the majority of PTHR transcripts in the human kidney. This was supported by a comparative analysis of promoter function using RNase protection probes $\mathrm{A}, \mathrm{B}$, and $\mathrm{C}$, which are specific to $\mathrm{P} 1-, \mathrm{P} 2-$, and $\mathrm{P} 3$-specific transcripts, respectively. $\mathrm{P} 3$ is the major human renal promoter, and $\mathrm{P} 2$ activity accounts for most of the remaining transcripts detected (Fig. $1 \mathrm{D}$, lanes 1-3). Indeed, under these conditions P1-specific transcripts were detected only after prolonged exposure (Fig. $1 D$, lane 4 ).

P3 initiation sites were mapped by primer extension analysis using a primer (Fig. $1 A$ ) whose $5^{\prime}$ end lies $70 \mathrm{bp}$ upstream of the $5^{\prime}$ end of SS. Two products of 140 and $147 \mathrm{~b}$ were detected (Fig. $2, K i d)$, which correspond to a novel fusion exon combining a $5^{\prime}$ exon of 210-217 bp in length (designated U4) and the previously identified SS exon. The 5' UTR contains an upstream open reading frame, suggesting that the transcript is subjected to translational regulation. These results are summarized in Fig. 3.

\section{ACG T Kid tRNA}

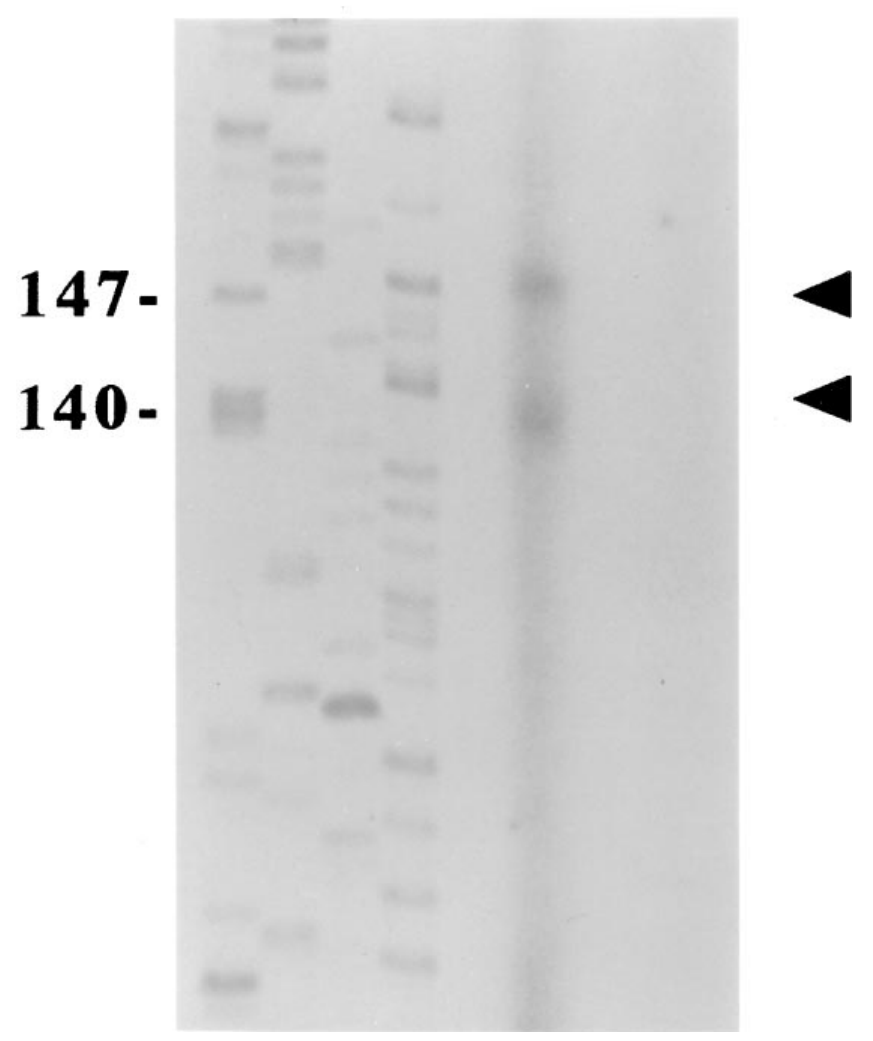

Figure 2. Identification of $\mathrm{P} 3$ promoter initiation sites by primer extension analysis. Primer extension was performed with a primer whose $5^{\prime}$ end lies 70 bp upstream of the $5^{\prime}$ end of SS (see Fig. $1 A$ ). Two extension products of 140 and $147 \mathrm{~b}$ are detected using human kidney total RNA but not with a tRNA control. The sequencing ladder used as molecular weight markers is shown on the left.

$P 2$ and $P 3$ promoters lie within a CpG island. The sequence of human genomic DNA between exons U3 and SS (Fig. $3 B$ ) revealed that $\mathrm{P} 2$ and $\mathrm{P} 3$ lie within the same $\mathrm{CpG}$ island. $\mathrm{CpG}$ dinucleotides occur at a frequency of 11 per $100 \mathrm{bp}$, with a $\mathrm{CpG} / \mathrm{GpC}$ ratio of approximately 1 in $1.3 \mathrm{~kb}$ of human sequence extending from 300 bp upstream of U3 to SS (Fig. 3, $A$ and $B$; reference 27 ). In contrast, a $1.1-\mathrm{kb}$ region around human P1 contains only $11 \mathrm{CpG}$ dinucleotides and a $\mathrm{CpG} / \mathrm{GpC}$ ratio of 0.12 (Fig. $3 A$; reference 27 ). Similar to other $\mathrm{CpG}$ island promoters (33), P3 lacks a discernible TATA box, is relatively $(\mathrm{G}+\mathrm{C})$-rich $(65 \%)$ between -250 and +100 , and contains a number of $\mathrm{Sp} 1$ sites (Fig. $3 \mathrm{~B}$ ). In the mouse, activity of the major renal promoter $\mathrm{P} 1$ is largely restricted to kidney and is weak or inactive in bone and cartilage $(26,27$, and unpublished results). The major human renal promoter, P3, resembles the $(\mathrm{G}+\mathrm{C})$-rich $\mathrm{P} 2$ promoter, which functions in a number of tissues in the mouse (25). Therefore, we analyzed the expression patterns of the three human promoters, in particular to determine if $\mathrm{P} 3$ functions in tissues other than kidney.

$P 3$ is widely expressed in human tissues and cell lines. Expression of PTHR coding sequence and of P2- and P3-specific transcripts was examined by semiquantitative RT-PCR analysis us- 
$\mathbf{A}$

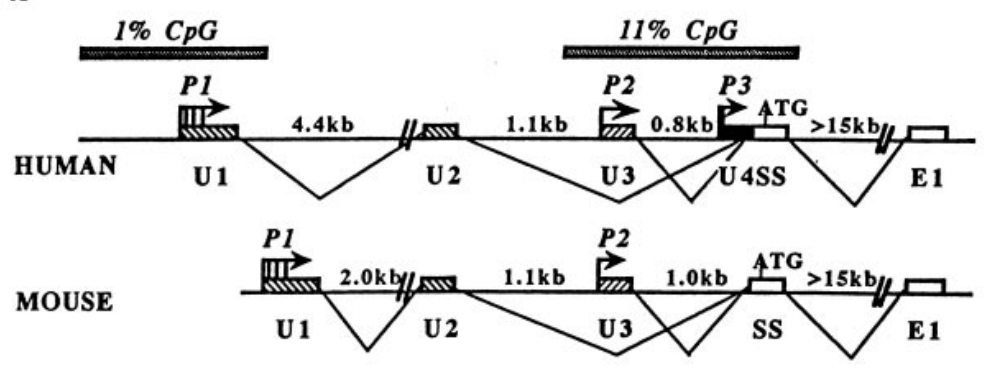

B
Figure 3. Sequence of the $\mathrm{P} 3$ promoter region. $(A)$ Structures of the $5^{\prime}$ ends of the regulatory regions of the mouse and human PTHR genes. The $\mathrm{CpG}$ content of sequences encompassing human promoter $\mathrm{P} 1$ and promoters $\mathrm{P} 2$ and $\mathrm{P} 3$ is indicated above. $(B)$ Sequence of the human $\mathrm{P} 3$ promoter region. $\mathrm{P} 3$ initiation sites are indicated by arrowheads, with the upstream site designated as +1 . Consensus Sp1 sites are indicated, and $\mathrm{CpG}$ dinucleotides are underlined. The sequence of the U4/SS exon is indicated in bold. The ATG start and TAG stop codons corresponding to the extremities of the open reading frame lying upstream of the PTHR coding sequence are boxed, as is the ATG (italics) of the PTHR coding sequence. ing specific primers (see Fig. $1 A$ ). Low-abundance P1-specific sequences were more highly amplified. In addition, $\beta$-actin sequences were amplified to control for differences in the relative total RNA concentrations. Amplified PTHR cDNA sequences were transferred to membranes and probed with internal oligonucleotides that were distinct from PCR primers (Fig. 4). PCR sequencing was also used to confirm that the amplified products corresponded to expected PTHR cDNA fragments (data not shown). As expected, the highest levels of expression of PTHR coding sequences were found in kidney (Fig. $4 A$, lane 14), with lower levels detected in spleen and bowel (Fig. $4 A$, lanes 16 and 18). Lower levels of expression were detected in human osteoblast-like osteosarcoma cell lines HOS (Fig. $4 A$, lane 6), SaOS-2 (lane 10), and U2OS (lane 8), in cultures of human skin fibroblasts (lane 12), the renal epithelial cell line HK-2 (lane 4), and in the breast carcinoma cell line MCF-7 (lane 2). Actin sequences were amplified to similar degrees in all tissues and cell lines studied (Fig. 4, bottom), suggesting that the wide range of amplification of PTHR coding sequences from different tissues was due to variation in expression levels and not to variable RNA concentrations in RT reactions. This is supported by Northern analyses of PTHR transcripts showing a wide variation of expression levels in different rat and human tissues $(8,16$, data not shown).

Consistent with results obtained in the mouse (25), P1 expression was restricted to kidney (Fig. 4, lane 14). P2-specific transcripts were detected in all human tissues and cell lines expressing PTHR coding sequences, consistent with P2 activity in the mouse (25). However, cDNA sequences amplified from
HOS cell extracts were shorter than the predominant products amplified from other tissues and cell lines (Fig. 4, lane 6; see below). P3-specific transcripts were detected in all PTHR-positive tissues and cell lines, except MCF-7, HK2, and U2OS (Fig. 4 D, lanes 2, 4, and 8), demonstrating that $\mathrm{P} 3$ expression is not restricted to kidney. RT-PCR analysis was also performed on RNA from adult mouse tissues and cell lines using P3-specific primers complementary to mouse sequences, and in all cases the results were negative (data not shown). Thus, we found no evidence for P3 activity in adult mice. Given that the major renal promoter in humans, P3, is widely active, and that predominant renal promoter in mouse, $\mathrm{P} 1$, is highly selective for kidney, our results indicate that PTHR gene expression is coordinated differently in the two organisms.

P3 sequences drive expression of a heterologous gene in transiently transfected HOS cells. PTHR promoter-luciferase reporter recombinants were constructed to analyze the function of promoter sequences in driving expression of heterologous reporter genes (Fig. $5 A$ ). Transient transfections were performed in HOS cells, which were shown to express P2- and P3specific transcripts (Fig. 4). Consistent with this observation, both $\mathrm{P} 2$ and $\mathrm{P} 3$ promoter sequences drove expression of luciferase activity in HOS cells, whereas little or no activity of P1 was observed (Fig. $5 \mathrm{~B}$ ). These results confirm the capacity of sequences in the $\mathrm{P} 3$ region to function as a promoter in driving expression of heterologous genes.

Expression of P2, but not P1 or P3, in fetal tissues. Analysis of PTHR gene expression was extended to RNA derived from tissues of 19-week FA human fetus (Fig. 6). PTHR cod- 


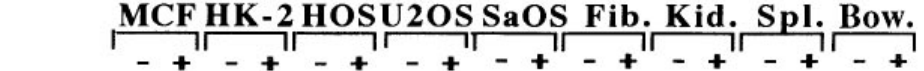

Cod.

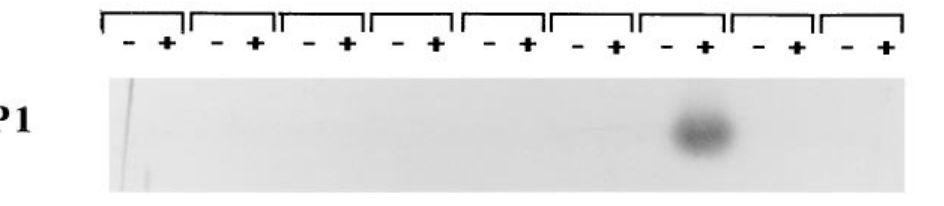

$-148$

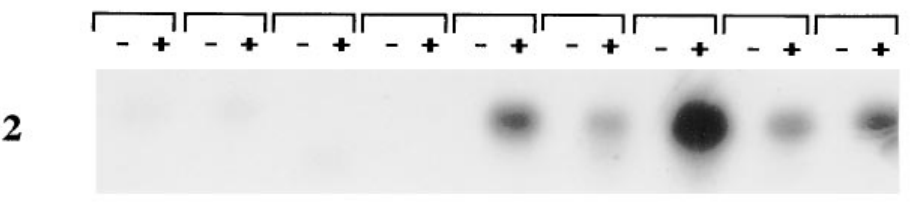

P2

$-187$

P3

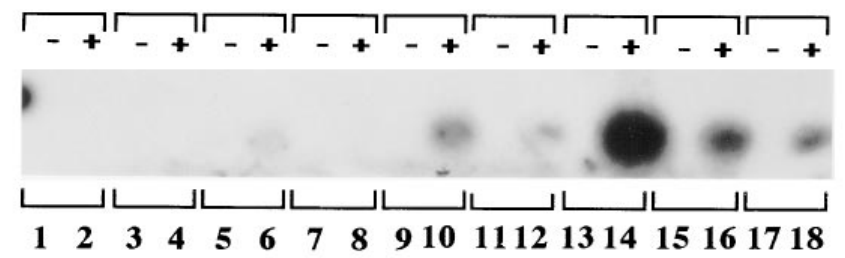

$-183$

$-342$
Figure 4. Tissue-specific expression of PTHR transcripts in adult human tissues and cell lines. Promoter-specific expression was analyzed by RT-PCR using PCR primer combinations diagrammed in Fig. $1 A$. P1-specific sequences were amplified using primers 1 and 6 , followed by amplification with primers 2 and 3. P2- and P3-specific sequences were amplified using primers 4 and 6 , and 5 and 6, respectively. Coding region sequences

$(\mathrm{Cod}$.) were amplified using forward and reverse primers derived from sequences in exons $\mathrm{T} 3 / 4 \mathrm{a}$ and $\mathrm{C} 1$, respectively, and detected using a probe derived from sequences in exon T6/7a. PCR conditions for coding region, P2-, P3-specific, and $\beta$-actin sequences were chosen so as to be in the linear range for amplification of RT products of kidney RNA (data not shown), whereas reactions performed with P1-specific primers were amplified beyond the linear range (see Methods for details of PCR conditions). Amplifications were performed on total RNA from MCF-7 breast carcinoma cells $(M C F)$, the renal epithelial cell line HK-2, osteoblast-like osteosarcoma lines HOS, U2OS, and SaOS-2 ( $\mathrm{SaOS})$, human skin fibroblasts (Fib.), and human kidney (Kid.), spleen $(S p l$.), and bowel (Bow.) treated with reverse transcriptase $(+)$, or untreated controls $(-)$. The sizes of the amplified products are given to the right of each panel. ing sequences were detected by RT-PCR in RNA from liver, long bone, calvaria, muscle, and kidney (Fig. 6, lanes 1-10). No P1-specific expression was detected after extended amplification in any of the fetal tissues studied, including kidney, under conditions where P1-specific RNA was readily detected in an adult kidney sample (Fig. 6, lane 12). Consistent with its broad expression in adult tissues and cell lines, P2-specific transcripts were detected in all of the tissues tested. Strikingly, however, we did not detect any P3-specific transcripts in kidney or any of the other tissues, under conditions where an amplified product was detected with adult kidney RNA (Fig. 6, lane 12). Essentially identical results were obtained with tissues from a 17.5-week fetus (data not shown). Further analysis of PTHR expression in long bone at 15.7 weeks FA and calvaria at 14.5 weeks FA (Fig. 6, lanes 14 and 16) showed that only P2-specific PTHR transcripts were present. Thus, although both P2 and $\mathrm{P} 3$ are $(\mathrm{G}+\mathrm{C})$-rich and lie within the same $\mathrm{CpG}$ island, they are clearly differentially regulated during development. These results also indicate that $\mathrm{P} 2$ is the major PTHR promoter active at midgestation, and moreover that the onset of expression of P1 and P3 in kidney occurs after 19 weeks FA.

Differential splicing of P2-specific transcripts in adult, but not fetal tissues. The shorter P2-specific RT-PCR product amplified from HOS cells (Fig. 4) was further investigated by subcloning and sequence analysis. The shorter fragment arose from differential splicing between U3 and SS exons using donor and acceptor sites distinct from those previously identified (Fig. 7). The sequence AGGCGG is present at both the donor and acceptor sites, preventing the unambiguous determination of the splice junction (Fig. 7, bold). There is an AG dinucleotide in the splice acceptor region; however, no GT dinucleotide is present in the splice donor, suggesting that a nonconsensus sequence is used. Structural analyses suggest that the differentially spliced $5^{\prime}$ UTR forms a less stable hairpin loop which liberates the ATG of the PTHR open reading frame from secondary structure (data not shown).

The cell and tissue specificity of the alternative splice was probed with an oligonucleotide that encompasses the alternative splice junction (Fig. $7 A$ ) and detects both long and short cDNA fragments under the hybridization conditions used. The blot revealed the existence of shorter products amplified as expected from HOS cells (Fig. $6 \mathrm{~B}$, lane 6 ), and from skin fibroblasts, kidney, and spleen (Fig. $7 \mathrm{~B}$, lanes 12, 14, and 16), but not from MCF-7, HK-2, U2OS, SaOS-2, or bowel even after extended exposure (Fig. $7 \mathrm{~B}$, lanes 2, 4,8, and 18; and data not shown). No evidence for alternative splicing was observed in 18- or 19-week FA tissue samples, including kidney, bone, and calvaria (Fig. $7 \mathrm{C}$ ), and similar results were obtained with bone and calvarial samples from earlier fetal stages (data not shown). The observation that the alternative splice occurs in 
$\mathbf{A}$

\section{Promoter}

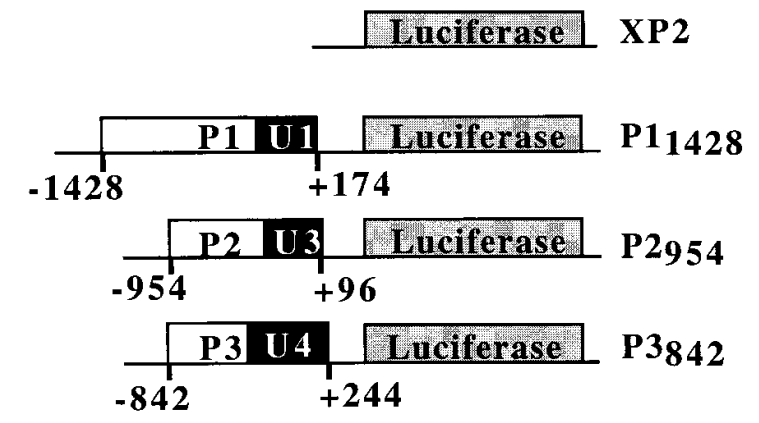

B

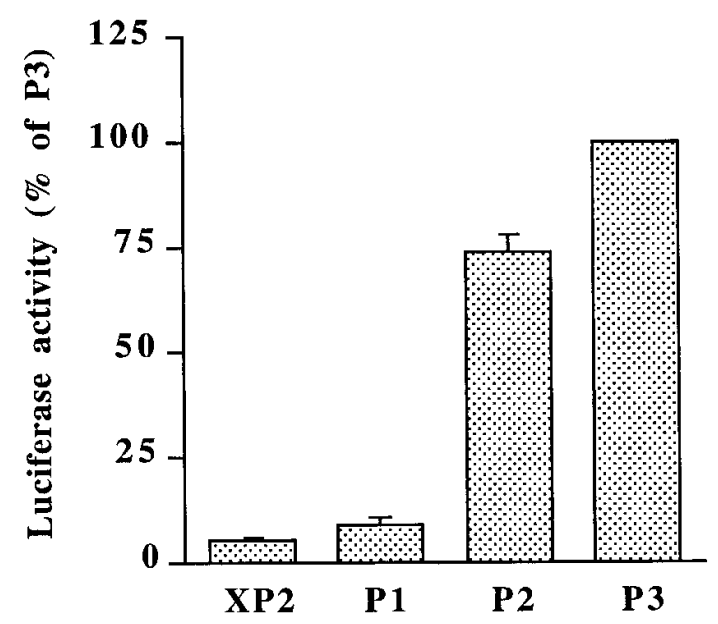

Figure 5. Function of $\mathrm{P} 3$ promoter sequences in transiently transfected HOS cells. $(A)$ Luciferase reporter recombinants used in these studies. See Methods for details of plasmid constructions. (B) Results of transient transfections of HOS cells with promoterless luciferase recombinant $\mathrm{pXP} 2$ or with recombinants containing $\mathrm{P} 1, \mathrm{P} 2$, or $\mathrm{P} 3$ sequences. Relative luciferase activities observed in three to five sets of transfections $( \pm$ SEM) are indicated.

adult but not fetal kidney indicates that the event is developmentally regulated.

\section{Discussion}

PTHR gene expression in kidney. P1 activity in the adult mouse accounts for at least $90 \%$ of PTHR transcripts in kidney (25, 26). Renal PTHR gene transcription in the mouse is thus largely controlled by kidney-specific regulatory sequences of $\mathrm{P} 1$. While $\mathrm{P} 1$ is active specifically in adult kidney, it accounts for only a small proportion of renal transcripts (Fig. 1; reference 27). In contrast, the P3 promoter drives the majority of PTHR gene transcription in human adult kidney. P3-specific transcripts are also expressed in a number of other tissues and cell lines, suggesting that common regulatory signals control human PTHR gene expression in renal and nonrenal tissues.

Studies of PTHR mRNA and protein expression in murine kidney revealed a cell-specific distribution of receptor protein and P1- and P2-specific mRNAs (26). Highest densities of
PTHR protein and transcripts were found in peritubular endothelial cells and vascular smooth muscle. PTHR mRNA expression in these cells was controlled exclusively by P1. Activity of P1 was also detected at moderate levels in tubular epithelial cells and in glomerular podocytes (26). The weak activity of P1 in human kidney suggests that either P1 is widely active at low levels, or that the expression pattern of P1-specific transcripts is much more restricted than in mouse. It should be noted that human kidney samples used in this study, which are derived from cortex and medulla, may not be fully representative of all renal cell types which express the PTHR. However, while P1 activity may be somewhat higher in specific cell types, it is clearly much less active in human than in mouse.

The moderate activity of $\mathrm{P} 2$ in murine kidney was found to be restricted to tubular epithelial cells (26). It is noteworthy that human P2-specific transcripts, but not those of P1 or P3, were detected in the renal epithelial cell line HK2 (Fig. 4), suggesting that $\mathrm{P} 2$ transcripts may have similar distributions in mouse and human kidney. The replacement of P1 by P3 as the major human renal promoter driving PTHR gene transcription suggests that the regulatory signals controlling PTHR expression in the kidney may differ between mouse and human. It is not clear whether P3 activity in human kidney simply replaces reduced $\mathrm{P} 1$ function in some cell types. The distribution and relative expression levels of PTHR transcripts and protein in different renal cell types may differ between mouse and human. It will therefore be important to determine the cellular distribution of PTHR transcripts and protein in human kidney.

Our results limit the number of potential models for the PTH resistance syndrome pseudohypoparathyroidism type $1 \mathrm{~b}$ (PHP1b). Previous work suggested that PHP1b arises from a defect in renal PTHR function that is not caused by mutations affecting PTHR sequence or splicing of P1- or P2-specific transcripts $(27,34-37)$. The broad activity of P3 suggests that PHP1b does not arise from mutations in proximal $\mathrm{P} 3$ promoter sequences. A defect in a kidney-specific PTHR gene enhancer could give rise to PHP1b in some patients. However, results point more toward mutations that disrupt function of a kidneyspecific transcription factor that drives renal PTHR gene expression, or a defect in a downstream component of the PTH/ PTHR signaling pathway, as supported by preliminary mapping studies that exclude the PTHR gene in some families (37).

$P 2$ is the major human PTHR promoter during midgestational fetal development. Although P3-specific transcripts were readily detectable by RT-PCR in adult human tissues and cell lines, no P3-directed expression was observed in tissues from human fetuses ranging from 14.5 to 19 weeks FA, even after extensive amplification. No evidence was found for activity of P1 in 17.5- or 19-week FA kidney (Fig. 6, and data not shown). In contrast, P2-specific transcripts were detected in several fetal tissues, including kidney, long bone, and calvaria (Fig. 6, and data not shown). This indicates that the highly conserved P2 promoter controls PTHR gene expression in kidney at midgestation, and that $\mathrm{P} 1$ and $\mathrm{P} 3$ function later.

Very little is known about PTHR function in fetal kidney. Although the placenta plays an important role in fetal calcium homeostasis, PTH or PTHrP may control fetal renal tubular function, providing a role for the PTHR expressed in fetal kidney (38). Upregulation of P1 and/or P3 activity could occur in preparation for, or in response to, the dramatic changes in kidney function that occur at parturition, when the fetus leaves an environment in which calcium homeostasis is controlled 


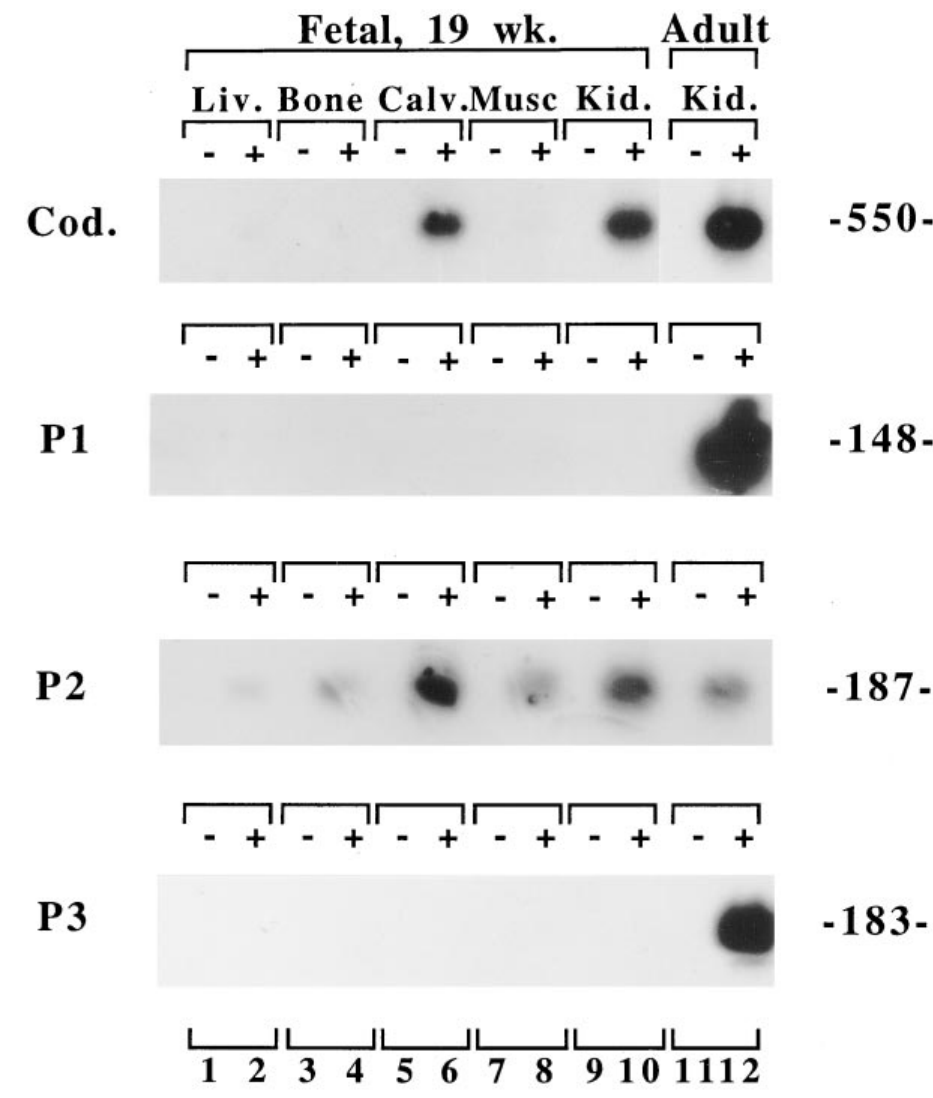

Fetal, 19 wk.

15.714 .5

Bone Calv.

ז+

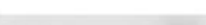

$550-$
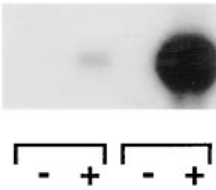

$-+$

$148-$
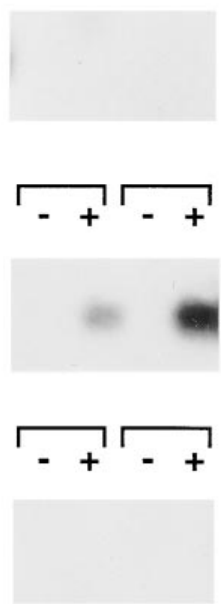

$\stackrel{1314}{1516}$
Figure 6. Expression of $\mathrm{P} 2$, but not $\mathrm{P} 1$ or P3 during the midgestational stage of fetal development. Expression of coding and promoter-specific PTHR sequences was analyzed by RT-PCR using the conditions described in Fig. 4, except that all products were amplified beyond the linear range (see Methods for details). Total RNA was from kidney (Kid.), liver (Liv.), muscle (Musc), calvaria (Calv.), and long bone (Bone) of a 19-week FA fetus, as well as long bone and calvaria from samples of 15.7- and 14.5-week FA fetuses; long bone and muscle samples were taken from femur and thigh, respectively. An adult kidney RNA sample was used as a positive control. RNA samples treated with reverse transcriptase $(+)$ or untreated controls $(-)$ are shown. largely by the placenta. At this stage, it would be expected that PTHR expression would be stimulated to accommodate the increased function of the kidneys. Stimulation of PTHR expression would increase the inhibitory effects of PTH on renal reabsorption of sodium, bicarbonate, and phosphate through its downregulation of $\mathrm{Na}^{+} / \mathrm{H}^{+}$and $\mathrm{Na}^{+} /$phosphate exchangers. Downregulation of both exchangers by PTH is at least partly dependent on stimulation of phospholipase C $(39,40)$. Studies in renal epithelial LLC-PK1 cells expressing variable levels of receptors has shown that, unlike the response to cAMP, PTH stimulation of the PTHR is strongly dependent on receptor number (41). Thus, increasing the density of PTHRs would selectively enhance PTH stimulation of phospoholipase C.

It is not clear at this time whether expression of the PTHR is important for kidney development or maturation of kidney function ex utero. In gene ablation experiments, loss of receptor function did not result in any gross abnormalities in renal development in mice that survived to 18.5 days postconception $(13,14)$. However, in rodents, kidney development continues after birth (42), and it has not been determined whether PTHR null mice show impaired nephron development. While a role of the PTHR in kidney morphogenesis is uncertain, PTHR gene expression is clearly essential for normal skeletal development. PTHR and PTHrP null mice display similar defects in endochondral ossification, with reduced proliferation and accelerated ossification of chondrocytes $(13,14)$. RNase protection and in situ hybridization experiments in cell lines and tissue sections have shown that $\mathrm{P} 2$ is the major promoter controlling PTHR expression in both chondrocyte and osteoblast lineages in mice after birth (reference 25; and data not shown). Our present results indicate that $\mathrm{P} 2$ is the major
PTHR gene promoter in long bone and calvaria from 14.5 to 19 weeks FA in human fetuses (Fig. 5). In humans, ossification is initiated at approximately 7 weeks FA in the femur, at 9-12 weeks FA in calvarial bone, and continues throughout development (43). Taken together, these results suggest that, despite the differential regulation of PTHR gene expression in adult tissues in human and in mouse, the signals controlling PTHR gene expression during skeletal development are conserved. Regulation of PTHR gene expression in adult bone is likely to be more complex in human than in mouse, because both $\mathrm{P} 2$ and $\mathrm{P} 3$ were found to function in the human osteoblast-like cell lines HOS and SaOS-2 (Fig. 4).

Differential splicing of P2-specific transcripts. We also found that transcripts are differentially splicing between U3, and SS gives rise to a shortened 5' UTR. Both long and short UTRs are formed in kidney, spleen, and skin fibroblasts, whereas only the short UTR was detected in HOS cells (Fig. 7). No evidence for alternative splicing was found in fetal tissues. The splice acceptor contains the sequence UAGG, which corresponds to the consensus YAGG for AG acceptor sites. The corresponding splice donor sequence, GCGGGG, diverges from the consensus GURAGU $(44,45)$. However, this sequence corresponds to a variant that has been described (46) and which is considered to function by interacting with the U1 snRNA. Secondary structure analysis suggests that the shorter UTR has a less stable stem-loop structure in the region of the initiator ATG (data not shown), suggesting that it may be more efficiently translated. Extensive secondary structure in $5^{\prime}$ UTRs can inhibit translational initiation $(47,48)$. Further studies will have to be performed to assess the impact of the shorter 5' UTR on translation of PTHR gene transcripts. 
A

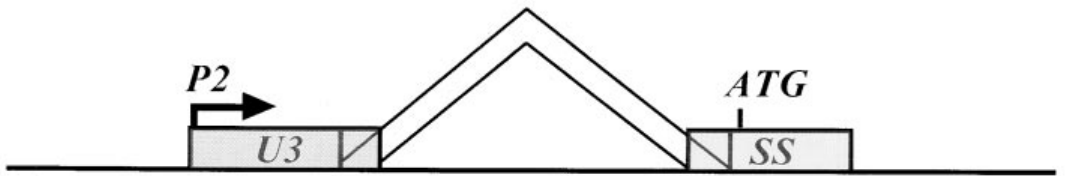

U3

....GGGTATCCCGAGAGCTCCATGAAGTCCCCCCGGGGCCGCGGACGGGGCGCTGGCTTGGGGAGGCTGTCGGG

GGGGCCCGACATCCATGGCAAGGCGGGGGCGGGCGCTCGGA GTAA....

SS

....CCACCAG GGCCGGCGGCGGCGGCTGCCCCGAGGGACGCGGCCCTAGGCGGTGGCGTG;GGACCGCCG

GATCGCACCCGGCCTGGCGCTCCTGCTCTGCTGCCCCGTGCTCAGCTCCGTACGCGCTG GTGAGT....

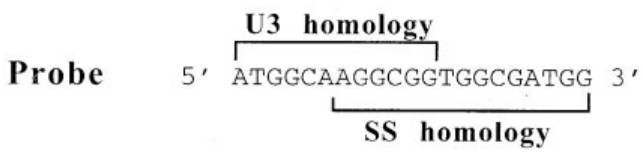

B

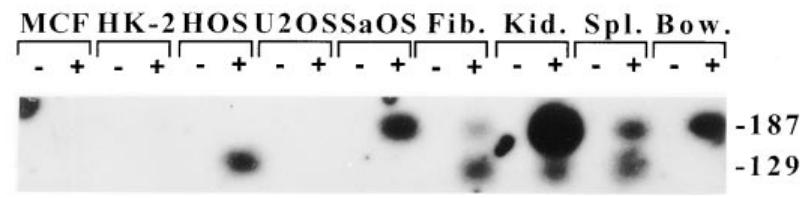

C

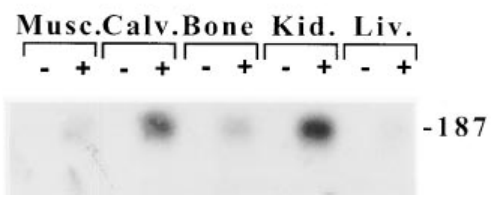

Figure 7. Differential splicing between exons $\mathrm{U} 3$ and SS gives rise to shortened $\mathrm{P} 2$-specific transcripts. (A) Schematic representation of the splicing patterns between U3 and SS. The sequences of the $3^{\prime}$ end of $\mathrm{U} 3$ and all of SS are presented below. The previously characterized splice donor site at the $3^{\prime}$ end of U3, and acceptor and donor sites at the extremities of SS are in italics. The ATG (italics) of the PTHR coding sequence is boxed. The putative splice donor and acceptor sites (arrowheads) were chosen based on the use of the consensus splice acceptor sequence. Note that splice donor and acceptor sites cannot be determined unambiguously because of the sequence AGGCGG (bold) present in both exons. The sequence of the oli-

gonucleotide probe used for Southern analysis that corresponds to the fusion between U3 and SS caused by the differential splice is presented at the bottom. $(B)$ Southern analysis of the blot of P2-specific RT-PCR products presented in Fig. 4 probed with the oligonucleotide presented in $A$. Products corresponding to previously characterized splice sites (187 bp) and the differentially spliced product (129 bp) are indicated. $(C)$ Southern analysis of P2-specific RT-PCR products amplified from fetal RNA probed with the oligonucleotide presented in A. Muscle (musc.), calvaria (calv.), bone, and kidney (kid.) were from 18-week FA tissue, whereas liver (liv.) was from a 19-week FA sample.

In summary, we have shown that expression of the PTHR gene in human and in mouse is regulated differently in the adult. The $\mathrm{P} 3$ promoter, which is apparently specific to human, drives the majority of renal PTHR gene transcripts and functions in a number of other tissues. $\mathrm{P} 2$ promoter activity is apparently well conserved, whereas $\mathrm{P} 1$ activity is much weaker in human than in mouse. P2 alone drives PTHR gene expression at midgestation, indicating that factors controlling $\mathrm{P} 2$ regulate PTHR gene expression during skeletal development. These results document the complexity of promoter functions that control the developmental- and tissue-specific expression of the human PTHR gene.

\section{Acknowledgments}

We are grateful to Dr. Harriet S. Tenenhouse (McGill University, Montreal, Quebec, Canada) for RNA samples from 14.5- and 15.7week FA fetuses. We thank Dr. Paul Goodyer (McGill University) for critical reading of the manuscript.

This work was supported by Medical Research Council of Canada grants MT-12896 (to J.H. White), MT-5775 (to D. Goltzman), MT9315 (to G.N. Hendy), and by a grant from the National Cancer Institute (to D. Goltzman), and Kidney Foundation of Canada (to G.N. Hendy). J.H. White is a chercheur-boursier of the Fonds de Recherche en Santé du Québec. M. Minagawa is the recipient of a Royal Victoria Hospital Research Institute Fellowship. G.N. Hendy is the recipient of a Medical Research Council of Canada Scientist Award.

\section{References}

1. Goltzman, D., and G.N. Hendy. 1995. Parathyroid hormone. In Principles and Practice of Endocrinology and Metabolism, 2nd ed. K.L. Becker, editor. J.B. Lippincott Co., Philadelphia. 455-467.

2. Kronenberg, H.M. 1996. Parathyroid hormone: mechanism of action. In Primer on Metabolic Bone Diseases and Disorders of Mineral Metabolism, 3rd ed. M.J. Favus, editor. Raven Press, New York. 68-70.

3. Ikeda, K., M. Mangin, B.E. Dreyer, A.C. Webb, J.T. Posillico, A.F. Stewart, N.H. Bander, E.C. Weir, K.L. Insogna, and A.E. Broadus. 1988. Identification of transcripts encoding parathyroid hormone-like peptide in messenger RNAs from a variety of human and animal tumors associated with humoral hypercalcemia of malignancy. J. Clin. Invest. 81:2010-2014.

4. Stewart, A.F. 1993. Humoral hypercalcemia of malignancy. In Primer on Metabolic Bone Diseases and Disorders of Mineral Metabolism, 2nd ed. M.J. Favus, editor. Raven Press, New York. 61-63.

5. Strewler, G.D., and R.A. Nissenson. 1993. Parathyroid hormone-related peptide. In Primer on Metabolic Bone Diseases and Disorders of Mineral Metabolism, 2nd ed. M.J. Favus, editor. Raven Press, New York. 169-173.

6. Suva, L.J., G.A. Winslow, R.E.H. Wettenhall, R.G. Hammonds, J.M. Moseley, H. Diefenbach-Jagger, C.P. Rodda, B.E. Kemp, H. Rodriguez, E.Y. Chen, et al. 1987. A parathyroid hormone-related protein implicated in malignant hypercalcemia: cloning and expression. Science. 237:893-896.

7. Pausova, Z., J. Bourdon, D. Clayton, M.-G. Mattei, M.F. Seldin, N. Janicic, M. Rivière, J. Szpirer, G. Levan, C. Szpirer, et al. 1994. Cloning of a parathyroid hormone/parathyroid hormone-related peptide receptor (PTHR) cDNA from a rat osteosarcoma (UMR 106) cell line: chromosomal assignment of the gene in the human, mouse and rat genomes. Genomics. 20:20-26.

8. Urena, P., X.F. Kong, A. Abou-Samra, H. Juppner, H.M. Kronenberg, J.T. Potts, Jr., and G.V. Segre. 1993. Parathyroid hormone (PTH)/PTH-related peptide receptor messenger ribonucleic acids are widely distributed in rat tissues. Endocrinology. 133:617-623.

9. Juppner, H. 1996. Jansen's metaphyseal chondrodysplasia-a disorder due to a PTH-PTHrP receptor gene mutation. Trends Endocrinol. Metab. 7: $157-162$. 
10. Schipani, E., K. Kruse, and H. Juppner. 1995. A constitutively active mutant of PTH-PTHrP receptor in Jansen-type metaphyseal chondrodysplasia. Science. 268:98-100.

11. Schipani, E., C.B. Langman, A.M. Parfitt, G.S. Jensen, S. Kikuchi, S.W. Kooh, W.G. Cole, and H. Juppner. 1996. Constitutively activated receptors for parathyroid hormone and parathyroid hormone-related peptide in Jansen-type metaphyseal chondrodysplasia. N. Engl. J. Med. 335:708-714.

12. Amizuka, N., H. Warshawsky, D. Goltzman, and A.C. Karaplis. 1994. Parathyroid hormone-related peptide-depleted mice show abnormal epiphiseal cartilage development and altered endochondral bone formation. J. Cell Biol. 126:1611-1623.

13. Karaplis, A.C., A. Luz, J. Glowacki, R.T. Bronson, V.L.J. Tybulewicz, H.M. Kronenberg, and R.C. Mulligan. 1994. Lethal skeletal dysplasia from targeted disruption of the parathyroid hormone-related peptide gene. Genes Dev. 8:277-289.

14. Lanske, B., A.C. Karaplis, K. Lee, A. Luz, A. Vortkamp, A. Pirro, M. Karperien, L.H.K. Defize, C. Ho, R.C. Mulligan, et al. 1996. PTH/PTHrP receptor in early development and Indian Hedgehog-regulated bone growth. Science. 273:663-666.

15. Juppner, H., A.-B. Abou-Samra, M. Freeman, X.F. Kong, E. Schipani, J. Richards, L.J. Kolakowski, J. Hock, J.T. Potts, Jr., H.M. Kronenberg, et al. 1991. A G-protein-linked receptor for parathyroid hormone and parathyroid hormone-related peptide. Science. 254:1024-1026.

16. Abou-Samra, A.-B., H. Jüppner, T. Force, M.W. Freeman, X.F. Kong, E. Schipani, P. Urena, J. Richards, J. Bonventre, J.T. Potts, Jr., et al. 1992. Expression cloning of a parathyroid hormone/parathyroid hormone related peptide receptor from rat osteoblast-like cells: a single receptor stimulates intracellular accumulation of both cyclic AMP, and inositol triphosphate and increases intracellular free calcium. Proc. Natl. Acad. Sci. USA. 89:2732-2736.

17. Schipani, E., H. Karga, A.C. Karaplis, P. Hellman, L.-Y. Xie, J.T. Potts, Jr., H.M. Kronenberg, G.V. Segre, A.-B. Abou-Samra, and H. Jüppner. 1993. Identical complementary deoxyribonucleic acids encode a human renal and bone parathyroid hormone (PTH)/PTH-related peptide receptor. Endocrinology. 132:2157-2165.

18. McCuaig, K.A., J.C. Clarke, and J.H. White. 1994. Molecular cloning of the gene encoding the mouse parathyroid hormone/parathyroid hormonerelated peptide receptor. Proc. Natl. Acad. Sci. USA. 91:5051-5055.

19. Kong, X.-F., E. Schipani, B. Lanske, H. Joun, M. Karperian, L.H.K. Defize, H. Juppner, J.T. Potts, Jr., G.V. Segre, H.M. Kronenberg, et al. 1994. The rat, mouse and human genes encoding the receptor for parathyroid hormone and parathyroid hormone related peptide are highly homologous. Biochem. Biophys. Res. Commun. 200:1290-1299.

20. Lin, S.-C., C.-R. Lin, I. Gukovsky, A.J. Lusis, P.E. Sawchenko, and M.G. Rosenfeld. 1993. Molecular basis of the little mouse phenotype and implications for cell type-specific growth. Nature. 364:208-213.

21. Maget, B., M. Tastenoy, and M. Svoboda. 1994. Sequencing of eleven exons in genomic DNA encoding rat glucagon receptor and multiple alternative splicing of its mRNA. FEBS Lett. 351:271-275.

22. Sreedharan, S.P., J.-X. Huang, M.C. Cheung, and E.J. Goetzl. 1995. Structure, expression and chromosomal localization of the type I human vasoactive intestinal peptide receptor gene. Proc. Natl. Acad. Sci. USA. 92:2939-2943.

23. Zolnierowicz, S., P. Cron, S. Salinas-Toldo, R. Fires, H.Y. Lin, and B.A. Hemmings. 1994. Isolation, characterization and chromosomal localization of the porcine calcitonin receptor gene. J. Biol. Chem. 269:19530-19538.

24. Joun, H., B. Lanske, M. Karperien, F. Qian, L. Defize, and A. AbouSamra. 1997. Tissue-specific transcription start sites and alternative splicing of the parathyroid hormone (PTH)/PTH-related peptide (PTHrP) receptor gene: a new PTH/PTHrP receptor splice variant that lacks the signal peptide. Endocrinology. 138:1742-1749.

25. McCuaig, K.A., H. Lee, J.C. Clarke, H. Assar, J. Horsford, and J.H. White. 1995. Parathyroid hormone/parathyroid hormone related peptide receptor gene transcripts are expressed from tissue-specific and ubiquitous promoters. Nucleic Acids Res. 23:1948-1955.

26. Amizuka, N., H.S. Lee, M.Y. Kwan, A. Arazani, H. Warshawsky, G.N. Hendy, H. Ozawa, J.H. White, and D. Goltzman. 1997. Cell-specific expression of the parathyroid hormone (PTH)/PTH-related peptide receptor gene in kidney from kidney-specific and ubiquitous promoters. Endocrinology. 138:469481.
27. Bettoun, J.D., M. Minagawa, M.Y. Kwan, H.S. Lee, T. Yasuda, G.N. Hendy, D. Goltzman, and J.H. White. 1997. Cloning and characterization of the promoter regions of the human parathyroid hormone (PTH)/PTH-related peptide receptor gene: analysis of deoxyribonucleic acid from normal subjects and patients with pseudohypoparathyroidism type 1b. J. Clin. Endocrinol. Metab. 82:1031-1040.

28. Kothary, R., S. Clapoff, S. Darling, M.D. Perry, L.A. Moran, and J. Rossant. 1989. Inducible expression of an hsp68-lacZ hybrid gene in transgenic mice. Development. 105:707-714.

29. Nordeen, S.K. 1988. Luciferase reporter gene vectors for analysis of promoters and enhancers. Biotechniques. 6:454-458.

30. Ryan, M.J., G. Johnson, J. Kirk, S.M. Fuerstenberg, R.A. Zager, and B. Torok-Storb. 1994. HK-2: an immortalized proximal epithelial cell line from normal adult human kidney. Kidney Int. 45:48-57.

31. Munsick, R.A. 1984. Human fetal extremity lengths in the interval from 9 to 21 menstrual weeks of pregnancy. Am. J. Obstet. Gynecol. 149:883-887.

32. Tora, L., J. White, C. Brou, D. Tasset, N. Webster, E. Scheer, and P. Chambon. 1989. The human estrogen receptor has two independent nonacidic transcriptional activation functions. Cell. 59:477-487.

33. Antequera, F., and A. Bird. 1993. In DNA Methylation: Molecular Biology and Biological Significance. J.P. Jost and J.P. Saluz, editors. Birkhauser Verlag, Basel. 169-185.

34. Murray, T.M., L.G. Rao, M.M. Wong, J.P. Waddell, R. McBroom, C.S Tam, F. Rosen, and M.A. Levine. 1993. Pseudohypoparathyroidism with osteitis fibrosa cystica: direct demonstration of skeletal responsiveness to parathyroid hormone in cells cultured from bone. J. Bone Miner. Res. 8:83-91.

35. Schipani, E., S. Weinstein, C. Bergwitz, A. Iida-Klein, X.F. Kong, M. Stuhrmann, K. Kruse, M.P. Whyte, T. Murray, J. Schmidtke, et al. 1995. Pseudohypoparathyroidism type $1 \mathrm{~b}$ is not caused by a defect in the coding exons of the human parathyroid hormone $(\mathrm{PTH}) / \mathrm{PTH}$-related peptide gene. $J$. Clin. Endocrinol. Metab. 80:1611-1621.

36. Suarez F., J.J. Lebrun, D. Lecossier, B. Escoubet, C. Coureau, and C. Silve. 1995. Expression and modulation of a parathyroid hormone (PTH)/PTHrelated peptide receptor messenger ribonucleic acid in skin fibroblasts from patients with type Ib pseudohypoparathyroidism. J. Clin. Endocrinol. Metab. 80: 965-970.

37. Ding, C.-L., T.B. Usdin, M. Labuda, and M.A. Levine. 1996. Molecular genetic analysis of pseudohypoparathyroidism type $1 \mathrm{~b}$ : exclusion of the genes encoding the type 1 and type 2 receptors. J. Bone Miner. Res. 11:S302.

38. Kovacs, C.S., and H.M. Kronenberg. 1997. Maternal-fetal calcium and bone metabolism during pregnancy, puerperium and lactation. Endocrinol. Rev. 18:832-872.

39. Muff, R., J.A. Fischer, J. Biber, and H. Murer. 1992. Parathyroid hormone receptors in control of proximal tubule function. Ann. Rev. Physiol. 54: 67-79.

40. Azarani, A., D. Goltzman, and J. Orlowski. 1995. Parathyroid hormone and parathyroid hormone-related peptide inhibit the apical $\mathrm{Na}^{+} / \mathrm{H}^{+}$exchanger NHE-3 isoform in renal cells $(\mathrm{OK})$ via a dual signaling cascade involving protein kinase A and C. J. Biol. Chem. 270:20004-20010.

41. Gou, J., A. Iida-Klein, X. Huang, A.B. Abou-Samra, G.V. Segre, and F.R. Bringhurst. 1995. Parathyroid hormone (PTH)/PTH-related peptide receptor density modulates activation of phospholipase $\mathrm{C}$ and phosphate transport by PTH in LLC-PK1 cells. Endocrinology. 136:3884-3891.

42. Wintour, E.M. 1997. The renin-angiotensin system and the development of the kidney. Trends Endocrinol. Metab. 8:199-207.

43. Crelin, E.S. 1981. Development of the musculoskeletal system. In CIBA Clinical Symposia, Vol. 31. CIBA Pharmaceutical Co., Basel, Switzerland. 2-36.

44. Keivi, J.-P., and A.I. Lamond. 1996. RNA splicing: unexpected spliceosome diversity. Curr. Biol. 6:802-805.

45. Tarn, W.-Y., and J.A. Steitz. 1997. Pre-mRNA splicing: the discovery of a new spliceosome doubles the challenge. Trends Biochem. Sci. 22:132-137.

46. Jackson, I.G., 1991. A reappraisal of non-consensus mRNA splice sites. Nucleic Acids Res. 19:3795-3798.

47. Kozak, M. 1991. Structural features in eukaryotic mRNAs that modulate the initiation of translation. J. Biol. Chem. 266:19867-19870.

48. Foyt, H., L.D. Leroy, and C.T. Roberts, Jr. 1991. Differential association of insulin-like growth factor I mRNA variants with polysomes in vivo. $J$. Biol. Chem. 266:7300-7305. 